Pedagogía y Saberes n. ${ }^{\circ} 54$

Universidad Pedagógica Nacional

Facultad de Educación. 2021. pp. 37-54

\title{
Comenius e a educação universal para ensinar todas as coisas*
}

\section{Comenius and Universal Education to Teach All Things}

Comenio y la educación universal para enseñar todas las cosas

Carlota Boto**

\section{Para citar este artículo}

Boto, C. (2021). Comenius e a educação universal para ensinar todas as coisas. Pedagogía y Saberes, (54). https//doi.org/10.17227/pys.num54-11521

* Este trabalho contempla uma investigação concluída, desenvolvida no âmbito do projeto temático da FAPESP 18/26699-4, intitulado Saberes e práticas em fronteiras: por uma história transnacional da educação.

** Professora titular da Faculdade de Educação da Universidade de São Paulo (USP).

Correo: reisboto@usp.br

Código Orcid: https://orcid.org/0000-0002-7389-2391. 


\title{
Resumo
}

Este artigo- resultado de uma investigação já concluída-tem por objetivo compreender as ideias pedagógicas de Comenius e averiguar sua atualidade. Assim, do ponto de vista metodológico, efetuou-se um estudo analítico das duas principais obras de Comenius - a Pampaedia (1971) e a Didática magna (1997). Tais livros foram estudados com a finalidade de compreender a distinção entre a escola projetada pelo educador e a realidade dos colégios e escolas de seu tempo. Comenius propõe um novo sistema de ensino, no qual o aprendizado se daria pelas coisas e por sua percepção sensível. Todo o ensino deveria calcar-se em um aprendizado anterior. Interessado nos princípios pedagógicos que levariam a uma facilidade no ensinar e no aprender, Comenius projeta aquilo que intitula educação universal. A ideia de universalidade expressa-se aqui porque ele acreditava na possibilidade de ensinar tudo a todos em diferentes graus de complexidade. Além disso, a ideia de universalidade compreendia o fato de que todos teriam acesso à escolarização: meninos e meninas, ricos e pobres, nobres e plebeus. Comenius supõe que um bom método seria suficiente para ensinar bem a todas as crianças. Esse método, dirigindo-se a todas as crianças de uma mesma classe, configura-se como ensino simultâneo. Tal modelo de ensino partia do pressuposto de que o conhecimento deverá articular o que já foi aprendido com aquilo que se propõe a ensinar em seguida. Nesse sentido, em alguma medida, Comenius é um dos pioneiros do ensino graduado. Procurou-se, ao final, verificar onde esse método ainda tem lugar, qual o potencial que ele ainda guarda e quais seus limites.

\section{Palavras-chave}

Comenius; ensino simultâneo; escola graduada; Filosofia da Educação; História da Educação

\begin{abstract}
This article-result of an investigation already completed-aims to understand Comenius' pedagogical ideas and ascertain their relevance. Thus, from a methodological point of view, an analytical study of the two main works of Comenius-Pampaedia (1971) and Didática magna (1997) was carried out. Such books were studied to understand the distinction between the school designed by the educator and the reality of the colleges and schools of his time. Comenius proposes a new teaching system, in which learning would take place through things and their sensitive perception. All teaching should be based on previous learning. Interested in the pedagogical principles that would lead to an ease in teaching and learning, Comenius designs what he calls universal education. The idea of universality is expressed herein because he believed in the possibility of teaching everything to everyone in different degrees of complexity. In addition, the idea of universality included the fact that everyone would have access to schooling: boys and girls, rich and poor, noble and commoners. Comenius assumes that a good method would be sufficient to teach all children well. This method, aimed at all children in the same class, is set as simultaneous teaching. This teaching model assumed that knowledge should coordinate what has already been learned with what it proposes to teach next. In this sense, to some extent, Comenius is one of the pioneers of graded education. In the end, we verified where this method still takes place, what potential it still has and what its limits are.
\end{abstract}

\section{Keywords}

Comenius; graded school; History of Education; Philosophy of Education; simultaneous teaching

\section{Resumen}

Este artículo, resultado de una investigación ya concluida, tiene como objetivo comprender las ideas pedagógicas de Comenio y determinar su relevancia. Así, desde un punto de vista metodológico, se realizó un estudio analítico de las dos principales obras de Comenio: la Pampedia (1971) y la Didáctica magna (1997). Dichos libros fueron estudiados para comprender la distinción entre la escuela diseñada por el educador y la realidad de los colegios y escuelas de su tiempo. Comenio propone un nuevo sistema de enseñanza, en el que el aprendizaje se llevaría a cabo a través de las cosas y su percepción sensible. Toda la enseñanza debería basarse en el aprendizaje previo. Interesado en los principios pedagógicos que facilitarían la enseñanza y el aprendizaje, Comenio diseña lo que él llama educación universal. La idea de universalidad se expresa aquí porque creía en la posibilidad de enseñar todo a todos en diferentes grados de complejidad. Además, la idea de universalidad incluía el hecho de que todos tendrían acceso a la escolarización: niños y niñas, ricos y pobres, nobles y plebeyos. Comenio asume que un buen método sería suficiente para enseñarles bien a todos los niños. Este método, dirigido a todos los niños de la misma clase, está configurado como enseñanza simultánea. Tal modelo de enseñanza se basaba en el supuesto de que el conocimiento debe articular lo que ya se ha aprendido con lo que se propone enseñar a continuación. En este sentido, hasta cierto punto, Comenio es uno de los pioneros de la educación graduada. Al final, intentamos verificar dónde se lleva a cabo este método, qué potencial tiene y cuáles son sus límites.

\section{Palabras clave}


A forma como cada um de nós constrói a sua identidade profissional define modos distintos de ser professor, marcados pela definição de ideais educativos próprios, pela adoção de métodos e práticas que colam melhor com a nossa maneira de ser, pela escolha de estilos pessoais de reflexão sobre a ação. É por isso que, em vez de identidade, prefiro falar de processo identitário, um processo único e complexo graças ao qual cada um de nós se apropria do sentido de sua história pessoal e profissional. Por que é que fazemos o que fazemos em sala de aula? Que saber mobilizamos na nossa ação pedagógica? (Nóvoa, 1998, pp. 28-29)

\section{Introdução: a escola como direito individual}

A escola moderna é uma instituição que nos acompanha desde o século XVI. 0 que dizer da educação e do modelo de escola que nos foi legado? Até que ponto a instituição faz jus aos tempos de hoje e até que ponto ela é já obsoleta? Em época de coronavírus, em inúmeros países, as aulas presenciais têm sido substituídas por ensino a distância. Se isso der certo, como fica a legitimidade dos saberes escolares? A escola, como se sabe, se fincou na modernidade como uma instituição pautada por uma prática e por um conjunto de regras deontológicas, que levam a que ela dialogue, não apenas com o universo do conhecimento, mas também com o território dos valores e da prescrição de conduta. Nesse sentido, a escola é uma instituição de formação, na acepção mais ampla que se possa dar ao tema. A proposta de um ensino inovador está na pauta da escolarização desde, pelo menos, o final do século XIX, quando o movimento da Escola Nova reivindica que a escolarização fosse transformada em prol de conferir maior protagonismo para o aluno, maior democracia nas relações pedagógicas, maior atenção para a autonomia da criança. Porém, se nós vistoriarmos a história e a filosofia da educação no início da Idade Moderna, poderemos encontrar a ânsia de renovação muito antes do surgimento desse momento da Educação Nova.

\section{Marco teórico-conceitual e metodologia}

Conforme argumenta António Nóvoa, foi entre os séculos XVI e XVIII, com a ação das congregações docentes, tanto no mundo católico quanto nos territórios marcados pelo protestantismo, que se foram progressivamente configurando um conjunto de saberes e de técnicas, um corpo de normas e de valores que se tornariam específicos da escola moderna (Nóvoa, 1991, p. 13). A elaboração desse conjunto de conhe- cimento sobre a educação e sobre a infância foi uma consequência do interesse da era moderna em pensar a temática da criança e consequentemente os modos de educá-la. Comenius é um dos principais autores que versou sobre a elaboração desse saber pedagógico que teria dado identidade à escolarização moderna. 0 resultado desse movimento moldou um formato de escola que, em alguma medida, chegou até nós.

A resposta à pergunta, Por que é que fazemos o que fazemos na sala de aula?, leva-me a evocar a mistura de vontades, de gostos, de experiências, de acasos até, que foram consolidando gestos, rotinas, comportamentos com os quais nos identificamos como professores. Cada um tem a sua maneira própria de organizar aulas, de se movimentar na sala, de se dirigir aos alunos, de utilizar os meios pedagógicos, uma maneira que constitui quase uma segunda pele profissional. (Nóvoa, 1998, p. 29)

Comenius é um autor que procurou, em seu tempo, organizar, sistematizar e propor um modelo de ensino que em muito se assemelha àquilo que veio a caracterizar nosso contemporâneo formato de escola. Conforme destaca Julia (2001), entre os séculos XVI e XVII, estruturava-se para o ensino "a realização de um espaço escolar à parte, com um edifício, um mobiliário e um material específicos" (p. 13). Nesse sentido, no século XVI nasciam os profissionais que se especializaram na educação. Portanto, o moderno modelo de escola surgia ali. Depois, no século XVIII, o Estado iria progressivamente tomar da Igreja o controle do ensino. De todo modo, continua Julia (2001), "estes três elementos, espaço escolar específico, curso graduado em níveis e corpo profissional específico, são essenciais à constituição de uma cultura escolar" (pp. 14-15). Demonstra Julia que a escola moderna - desenhada pelos colégios jesuíticos, mas projetada também por Comenius - não é apenas um local de aprendizado de saberes, mas é, ao mesmo tempo, "um lugar de inculcação de comportamentos e de habitus que exige uma ciência do governo transcendendo e dirigindo, segundo sua própria finalidade, tanto a formação cristã como as aprendizagens disciplinares (Julia, 2001, p. 22). Tratava-se, nesse sentido, de, por meio da escola, remodelar comportamentos, formar o caráter das almas, disciplinar o corpo e dirigir as consciências. 0 presente trabalho, mediante a análise de duas obras de Comenius-educador checo do século XVII -, a saber a Pampaedia e a Didática magna, procurará compreender como se formularam à guisa de ideais educativos algumas das premissas da escola, tal como a instituição chegou até nós. Há que se lembrar que, na Europa, o século XVII era um tempo em que a vida rural transformava-se. Conforme destaca Crouzet (1995), "os burgos crescem e enchem-se de artífices: curtidores, 
ferreiros, fundidores, vidreiros, cordoeiros, etc." (p. 169). Além disso, o comércio se expandia e, por tal razão, no cenário social novos protagonistas tomavam lugar na cidade. A escola é, antes de mais nada, uma instituição da cidade. 0 burguês daquele tempo pretendia tornar-se fidalgo, embora se distanciasse das maneiras de agir da aristocracia. A cultura letrada tornava-se progressivamente um requisito socialmente valorizado por essas camadas de uma burguesia enriquecida, a despeito de não ser, ainda, suficientemente difundida. Não é por acaso que tenha sido o século XVII que presenciou a expansão dos colégios. Não é por acaso que tenha sido nessa época que uma obra como a de Comenius foi elaborada.

Comenius advoga que o objetivo da educação é a possibilidade de viver uma vida plena, na qual a semente ou a potência humana seja efetivamente germinada, atualizada. Os benefícios da educação seriam situados no âmbito individual, já que a pessoa se desenvolve pessoalmente por ter sido instruída; mas seriam também benefícios públicos, dado que a própria coletividade seria agraciada com um benefício que se estenderia a todas as classes da sociedade. 0 ensino, porém, deveria seguir a ordem da natureza e adaptar-se às diferentes etapas da vida da infância e da juventude (Monroe, 1900, p. 168). Além disso, o ensino deve partir de um aprendizado anterior. Tudo pode ser ensinado, desde que por graus crescentes de complexidade, como se os saberes pudessem vir articulados entre si. 0 ensino seria, nesse sentido, graduado e simultâneo: todos os alunos de uma mesma classe deveriam ser ensinados ao mesmo tempo. Esse era basicamente o segredo de um método que se propunha a ensinar tudo a todos no menor espaço de tempo possível.

Comenius cria a pedagogia como um campo do conhecimento, posto que coloca questões sobre educação, acreditando que seria necessária uma expertise para poder responder às demandas feitas no território do ensino. Como funciona uma aula?. Como ensinar a criança, tendo atenção a suas fases de desenvolvimento? O que ensinar antes e o que ensinar depois? Ninguém pensava nisso antes. Ele pensou. Como proceder para fazer com que o aluno aprenda? Comenius, no discurso pedagógico, substitui a ideia de criança pela concepção de aluno. Em tal contexto surgia a ideia de Didática, expressa enquanto uma arte de ensinar. A Didática-e, mais do que ela, a Pedagogia-deveria "codificar um saber e regulamentar uma prática, para romper com a servidão das práticas rotineiras mais ligadas ao empirismo cego do que a uma clara consciência dos fins e dos meios" (Cauly, 1999, p. 183). Na Didática, nada poderia ser feito intempestivamente e ao acaso. A educação em geral e o ensino em particular exigiriam um método que era único, que era para todos e que era progressivo. 0 método seria, pois, o elemento agregador que unifica o saber da educação, para transformá-lo em uma Pedagogia.

\section{Biografia de Comenius}

Jan Amos Komenský-em latim, Comenius ou, em português Coménio (Gomes, 1985)-foi um educador e escritor checo, que é considerado pela literatura como o fundador da Didática. Comenius nasceu em Nivnitz, na Morávia, em 28 de março de 1592. Trata-se de uma região da Europa Central que integrava o reino da Boêmia e que hoje abarca a parte oriental da República Checa. Filho de um moleiro, desde criança, viveu no seio do grupo religioso da Unidade dos Irmãos Morávios. Sua família, eslava e protestante, era seguidora da Igreja dos Irmãos Morávios, a qual era fincada sobre as ideias de Jan Huss, defensor de uma vida simples e humilde. Esse modelo de educação teria influenciado toda a obra pedagógica de Comenius. Em 1604, com doze anos, Comenius torna-se órfão de pai e de mãe. Frequenta escolas dos irmãos morávios e, aos 19 anos, matricula-se na Universidade de Herborn, uma instituição calvinista, na qual cursará Teologia. Aos 21 anos, vai para a Universidade de Heidelberg, onde estuda Astronomia e Matemática. Depois, volta para a Morávia para atuar no magistério, como professor de escola. Em 1618, tem início a Guerrra dos 30 anos e, desde então, a vida de Comenius se dará em eterna turbulência. Nesse mesmo ano, Comenius torna-se reitor das escolas dos irmãos e casa-se com Madalena Vizovská. Entre 1620 e 1621, começou a haver uma intensa perseguição aos protestantes checos. Os exércitos espanhóis em 1621 invadiram e saquearam sua cidade, o que levou Comenius a perder sua mulher e dois filhos. Em função do ocorrido, Comenius, na Boêmia, escreveu, em 1623, o labirinto do mundo e o paraíso da alma. Em 1624, casa-se com Dorotéia Cyrillo, e os dois terão cinco filhos. Importante é destacar que, em meio a perseguições e guerras, Comenius nunca aceitou a desigualdade social e econômica. Para ele, os pobres eram vítimas de discriminação. Essa discriminação era absolutamente inaceitável, posto que, para ele, todos os homens, cristãos ou não cristãos, foram feitos à imagem e semelhança de Deus (Bédard, 2005, p. 56).

Em 1627, como aponta Kulesza (1992), "é impresso em Amsterdã um mapa detalhado da Morávia realizado por Comenius" (p. 16). No ano seguinte, o educador transfere-se para a Polônia, para a região de Leszno, fugindo da perseguição, e acompanhando, na época, a orientação dada pela própria Unidade 
dos Irmãos Morávios. Na Polônia, ele retoma suas atividades como pastor e como professor. Em Leszno, ensina em um ginásio da cidade e observa que, além de muitas classes abrigarem, por vezes, duzentos alunos de diferentes idades, os professores se limitavam a ditar para os alunos textos em latim (Bédard, 2005 , p. 58). Talvez tenha sido aí que Comenius se deu conta de que todo o ensino deveria principiar pelo conhecimento da língua materna. Nessa ocasião, Comenius inicia a redação de sua Didática Checa, que-também de acordo com Kulesza-seria concluída em 1632. Esse texto, escrito na língua materna de seu autor, foi publicado pela primeira vez apenas em 1844, na cidade de Praga. Em 1631 há uma peste na Polônia. Na ocasião, os Irmãos Morávios são acusados de promover o contágio e Comenius escreve um opúsculo em defesa deles. Em 1632, Comenius é eleito bispo da Unidade dos Irmãos. Seu papel, em sua nova condição, era o de assumir a orientação dos estudos e a organização dos jovens teólogos formados pela sua congregação. Nessa época, adquire grande notoriedade. Entre 1633 e 1636, Comenius buscava traduzir para o latim sua Didática Checa. Porém, para a tradução, ele fez inúmeras adaptações, o que teria transformado significativamente o texto original. Em 1636, ele torna-se reitor das escolas da Unidade dos Irmãos Morávios. Em 1638, Comenius conclui sua Didática Magna, escrita em latim, como uma versão ampliada de sua Didática Checa.

Entre 1641 e 1643, Comenius viaja para a Inglaterra, para a Holanda e para a Suécia, sendo que, no caso desta última, ele escreve livros didáticos voltados para a reforma das escolas suecas. 0 que é muito nítido em toda a trajetória de Comenius é a aliança entre teoria e prática. Ele era capaz de projetar teoricamente a realidade vivenciada. Talvez venha daí a força de seus tratados educacionais. Em 18 de abril de 1645, em uma carta dirigida a De Geer-conforme sublinha Gomes -, Comenius

menciona, além da Pansophia, também a Pampaedia como uma das sete partes dessa obra. Embora a obra não estivesse ainda completamente terminada, começaram a ser compostas tipograficamente algumas das suas partes, em Amsterdã, em setembro de 1656, com a intenção de serem enviadas a alguns amigos que lhe dessem sugestões, antes da impressão definitiva. (Gomes, 1971, p. 8)

A Pampaedia foi impressa pela primeira vez somente no século Xx. Em 1648, a esposa de Comenius veio a falecer e no ano seguinte ele casou-se novamente com Joana Gajus. Em 1650, ele é eleito Supremo Sacerdote da Unidade dos Irmãos. Em 1654, ele retorna a Leszno. Em 1656, Leszno será atacada e incendiada por poloneses católicos, deixando arrasada a situação também dos arquivos e das bibliotecas. Comenius perde tudo; inclusive seus manuscritos. Por causa disso, aceita um convite para ir morar em Amsterdam, onde viverá até 1670 , quando morre, deixando um conjunto significativo de obras inéditas. Em 1956, a Conferência Internacional da Unesco, em Nova Delhi (India), decidiu pela publicação de toda sua obra e reconheceu Comenius como um precursor das ideias de fraternidade e de solidariedade que posteriormente, quase 300 anos depois, teriam inspirado a fundação da Unesco.

\section{Pampaedia: uma educação universal, com professores universais em escolas universais}

A Pampaedia, no conjunto da obra de Comenius, era uma parte de sua Pansophia. Tanto no livro, quanto em sua mente, Comenius expressa firmemente a crença em uma sabedoria universal que pudesse vir a ser expressa por um modelo pedagógico comum a todas as matérias e passível de ser ministrado por qualquer professor. Comenius acreditava firmemente em uma reforma radical da sociedade, pautada, sobretudo, por uma nova concepção do conhecimento. Como destaca Gomes (1971), "as coisas humanas que Comenius pretende reformar resumem-se em três palavras: a eruditio, a política e a religio" (p. 16). Para Comenius - continua o comentador - seria fundamentalmente através da educação que o estado das coisas poderia ser transformado. Para tanto, ele propõe sete escolas: 1 . A escola da formação pré-natal; 2. A escola da infância; 3 . A escola da puerícia; 4 . A escola da adolescência; 5. A escola da juventude; 6. A escola da idade adulta; 7. A escola da velhice; 8. A escola da morte. À luz do exposto, verifica-se que Comenius acreditava em uma educação para a vida toda. Seu projeto pedagógico é fundamentalmente um plano de sociedade - de sua organização, sua política e seu funcionamento. Para formar uma nação equilibrada, em tempos de guerras e de epidemias, seria fundamental uma sólida formação, para a qual seriam necessárias as instituições que Comenius chamava de escolas universais. Sua aspiração de uma educação universal vinha expressa nas seguintes palavras:

Em primeiro lugar, o que se deseja é que assim se consiga educar plenamente para a plenitude humana, não apenas um só homem, ou alguns, ou muitos, mas todos e cada um dos homens, jovens e velhos, ricos e pobres, nobres e plebeus, homens e mulheres, numa palavra, todo aquele que nasceu homem para que, 
enfim, todo o gênero humano venha a ser educado, seja qual for a sua idade, o seu estado, o seu sexo e a sua nacionalidade. (Coménio, 1971, p. 38)

Mas o que significava ensinar a todos? Diz Comenius o que segue:

Ensinar a todos significa fornecer a todos os homens, de todas as idades e de todos os engenhos, um conhecimento mais completo das coisas. Ensinar todas as coisas, que aperfeiçoam a natureza humana, significa conhecer todas as coisas verdadeiras, escolher todas as coisas boas, fazer todas as coisas que é necessário saber na vida e na morte. Ensinar totalmente significa ensinar de modo a chegar ao fundo da questão, isto é: 1. solidamente e com segurança; 2 . com agrado e prazer; 3. rapidamente em todas as coisas e prudentemente por toda a parte. (Coménio, 1971, pp. 150-151)

No parecer de Comenius, um homem bem educado (homem ou mulher, diga-se de passagem) será formado de maneira pluridimensional, ou seja, para interagir com todas as matérias de estudo, para saber de todas as coisas. Por isso ele pretende que, nessa direção, "todos os homens sejam desde já iniciados na educação universal; em todas as coisas; para que se tornem totalmente cultos" (Coménio, 1971, p. 39). Só com uma educação transformada seria possível compreender as articulações entre as coisas, os pensamentos e as palavras. Nessa direção é que se apresentava o projeto de uma Pampaedia, que Comenius defendia como "o caminho aplanado através do qual a luz pansófica se difunde pelas mentes, pelas palavras, e pelas ações dos homens. Ou ainda, é a arte de transplantar a sabedoria nas mentes, nas línguas, nos corações e nas mãos de todos os homens" (Coménio, 1971, pp. 41-42). Por outras palavras, haveria de se ativar a mente, a língua e a mão, com exemplos, preceitos e exercícios: "porque, sem exemplos, nada se aprende facilmente; sem preceitos, nada se aprende racionalmente; sem a experiência, nada se aprende solidamente" (Coménio, 1971, p. 154). Era como se as coisas que se ouvem fossem transferidas dos ouvidos para os olhos e dos olhos para as mãos. Daí a necessidade de começar o ensino pelo conhecimento das coisas. Essas seriam apreendidas pelos sentidos e, por meio deles, penetrariam na inteligência. Para o educador checo, as coisas seriam ressignificadas tanto por meio da teoria, quanto por meio da prática e por sua utilização; ou seja, "por meio de regras, de exemplos e da experiência. As regras sejam poucas, mas claras, os exemplos sejam muitos e adaptados aos temas; a experiência seja muitíssima, até se transformar em hábito" (Coménio, 1971, p. 160).
Educar bem era, no parecer de Comenius, impedir que as pessoas degenerassem no que ele chamava de não-homem, e, nesse sentido, "desejar que não haja ninguém que não seja instruído; pois, dada a natureza humana, é facílimo que degenerem, sobretudo aqueles que não receberam instrução" (Coménio, 1971, p. 46). A proposta era a de que a educação se voltasse, primeiramente, para favorecer uma vida racional. Tal direcionamento implicaria a formação de pessoas sábias por outras pessoas também sabedoras. Comenius compreende que todo ser humano é passível de ser ensinado. Todos podem aprender, em virtude do fato de essa capacidade habitar a própria natureza humana. Se os homens são matricialmente iguais, também será equivalente a capacidade de cada um aprender, a despeito de, para tanto, haver variações quanto ao ritmo do aprendizado. As palavras de Comenius são, nesse sentido, esclarecedoras:

Tudo o que tu sentes querer, saber e conhecer, qualquer outro sente que o pode querer, saber e conhecer, uma vez que é dotado dos mesmos órgãos. Portanto, se todos os homens forem conduzidos pelos mesmos caminhos, não poderão deixar de chegar todos no mesmo lugar. Não há nenhuma diferença de natureza, embora possa haver talvez muitas diferenças de grau, pelo que um indivíduo compreende mais rapidamente que outro, ou reflete com mais profundidade ou retém mais duradouramente. No entanto, uma inteligência, um juízo, ou uma memória mais aguda ou mais lenta não é determinante para que se seja ou não seja homem, mas apenas implica que se aprenda mais rapidamente ou mais lentamente. (Coménio, 1971, p. 53)

Comenius pediu a Descartes que lesse seu trabalho e que o comentasse. Dizem os biógrafos (Cauly, 1999) que houve um encontro entre os dois, no qual Comenius foi recebido por Descartes, mantendo com ele uma reunião de aproximadamente quatro horas. Descartes, tendo comentado a obra comeniana, especialmente aquela vinculada a sua pansofia, foi um crítico da perspectiva do seu contemporâneo. Para Descartes, "a passagem (o salto?) da filosofia para a pansofia só pode efetuar-se se se abolir a linha de separação entre filosofia e teologia, entre saber e fé" (Cauly, 1999, p. 243). Com tal entendimento, Descartes interpretou que Comenius procurava resolver os problemas humanos apelando para a fé e que tal "salto" não se justificaria. De todo modo, Comenius colocava, não apenas Deus, mas toda a sua alma no projeto pedagógico que idealizou. 


\section{Sabedoria universal e cultura enciclopédica: pensamentos, palavras e ações}

Comenius acreditava-como parte de seu plano filosófico-em uma cultura universal, que se estruturaria como uma sabedoria universal, expressa por meio de uma cultura geral e enciclopédica. Era como se o conhecimento procedesse por círculos espirais, em um grau crescente de complexidade. Todos os homens (e ele inclui as mulheres quando se refere a homens) poderiam e deveriam ser instruídos enciclopedicamente. Somente isso poderia distingui-los efetivamente dos animais, a partir de três critérios: a razão, a linguagem e a atividade livre. Por atividade, Comenius compreende "a faculdade de produzir também, se quiser, com admirável habilidade, as coisas que entende e de que fala" (Coménio, 1971, p. 63). Assim, a razão determina a inteligência, a linguagem abarca as palavras e a atividade é o que resulta da ação das mãos. Pensamentos, palavras e ações constituiriam, pois, a dimensão humana em sua estrutura primeira. Só isso levaria o homem a ser capaz primeiramente de sabedoria; a seguir de eloquência; e finalmente de ação. Isso possibilitaria a convivência e a habilidade também humana de adquirir bons costumes e boas maneiras.

Enfim, porque todos os homens são educáveis, porque há uma igualdade matricial no gênero humano e porque uma sociedade deve estar fincada sobre a acepção de uma cultura universal, Comenius propõe uma escola que seja, ela também, universal. Diz isso com as seguintes palavras: "porque devem ser educados todos os homens, haverá, portanto, necessidade de escolas universais, como oficinas de cultura, para educar a todos. Para isso, servi-nos-emos do termo Panscolia" (Coménio, 1971, p. 103). Tais escolas precisariam de professores universais, "que saibam inculcar em todos, todas as coisas, totalmente" (Coménio, 1971, p. 104). Precisariam, ainda, de livros que contivessem todas as coisas a serem ensinadas. E, para que se reporte às próprias palavras de Comenius:

\footnotetext{
Além disso, será bom que sejam observadas e traduzidas na prática também as seguintes normas: I. Que cada homem, uma vez chegado ao uso da razão, se torne para si mesmo escola, livro, mestre; e como isso pode realizar-se. II. Que cada um seja para o seu próximo, nas suas relações mútuas, uma escola, um livro, um mestre. Finalmente que, em parte alguma, faltem escolas comuns, livros e mestres públicos. (Coménio, 1971, p. 105)
}

\section{Livros escolares como preceptores das novas gerações}

Comenius compreende que os requisitos essenciais de uma boa escola seriam os professores, os alunos e os bons livros. Note-se que ele não fala em qualquer livro: são bons livros. Sob tal perspectiva, defende uma leitura regrada, que passe por bons conteúdos, sistematicamente dispostos de modo a que o pensamento deslize, de maneira adequada, de um assunto a outro. O livro, em Comenius, é ele mesmo um educador. Ele ensina o professor a ensinar. Ensina também os alunos. Diz Comenius que "os livros escolares podem ser escritos de tal modo que, embora apresentando o mesmo texto, sirvam tanto para os principiantes, como para os adiantados e para os mais adiantados" (Coménio, 1971, p. 127). Assim, a linguagem do livro destina-se primordialmente ao aluno médio. Trata-se de um modelo de ensino, também ele, simultâneo, voltado exatamente para padronizar, tanto quanto possível, os graus de adiantamento dos diferentes grupos de alunos. Os livros deveriam, sobretudo, ser graduados e, nas palavras do educador checo, "organicamente concatenados" (Coménio, 1971, p. 128). Comenius diz que os livros teriam uma ordem tão clara que sequer precisariam de um índice. Os livros deveriam ser escritos de maneira límpida, de modo que fossem facilmente compreendidos pelos professores, facilmente explicados para os alunos e facilmente apreendidos também pelos autodidatas, fora da escola.

A proposta de Comenius é a de que os livros escolares não fossem - por suas palavras - "depósitos de erudição e de sabedoria” (Coménio, 1971, p. 129). Os livros seriam, antes, os funis mediante os quais a sabedoria de Deus pudesse se transportar para os espíritos. Nos termos de Comenius:

Em suma, todo o livro do nosso tempo (sobretudo o escolar) deverá ser inteiramente pansófico, inteiramente pampédico, inteiramente panglótico, inteiramente panortótico. Pansófico: que oferece a medula de toda a sabedoria plena, cada um segundo o seu grau, mais concisamente ou mais difusamente. Pampédico: servindo a todos os espíritos em tudo, e também cada um segundo o seu grau. Panglótico: traduzível em todas as línguas dos povos, dada a facilidade do seu estilo simples. Panortótico: que serve eficazmente para prevenir ou para corrigir as corruptelas das coisas, também cada um segundo o seu lugar e o seu modo. (Coménio, 1971, p. 130)

Note-se que, em conformidade com o que ocorria em sua época, Comenius não defende a leitura de qualquer livro. Trata-se de triar a avalanche de material escrito que todos os dias se ampliava. Os livros 
considerados nocivos deveriam ser abolidos, os livros inúteis, desautorizados, de modo a que se pudesse efetivar o uso de livros considerados bons. Um livro bom não seria aquele carregado de citações. Um livro bom seria um livro universal, que contivesse, portanto, toda a matéria. Além disso, os livros seriam metódicos, "isto é, se fazem avançar a inteligência espontaneamente, de grau em grau" (Coménio, 1971, p. 233). Os livros precisariam, ainda, ser ornados com figuras; e seus títulos deveriam ser inspirados na jardinagem - plantarium, seminarium, violarium, rosarium, etc. Os livros seriam, sobretudo, graduados, com informações cada vez mais complexas, de maneira a facilitar o entendimento das crianças. Em Comenius, o segredo do ensino reside no fato de ele ser progressivo.

Conforme destaca Piobetta (s/d, p. 133), cada etapa do ensino deveria contemplar um conjunto completo de conhecimentos que seria o ponto de partida, depois, para estudos mais elevados, mais aprofundados e mais extensos. Os programas de estudos seriam sistematizados em livros, mas não muitos: "que os livros sejam poucos. Se o mundo deve ser libertado do dilúvio dos livros, que o seja imediatamente, logo desde a primeira instrução (...); que os programas contidos nos livros sejam de tal extensão que ocupem comodamente todo o espaço de tempo da puerícia, de modo que não reste tempo para coisas frívolas e más" (Coménio, 1971, p. 234). Desse modo, o mesmo livro que é objeto de cobiça, é algo visto com temor e com má-vontade. 0 livro é valorizado? Depende de qual livro. É preciso, no entanto, reconhecer - e Comenius pensa assim - que o livro escolar é um grande guia, que fornece instrumental imprescindível ao professor para que esse dê ordem ao percurso de seu ensino. Por ser assim, é preciso que livros criteriosamente elaborados para o ensino sejam, de fato, "utilizados de modo que, pouco tempo depois, possam ser postos de parte" (Coménio, 1971, p. 235).

Mas como os livros deveriam ser lidos? "Sempre com atenção; fazendo seleções e extratos" (Coménio, 1971, p. 308). Os extratos e as seleções eram instrumentos necessários para ler os autores, para verificar, nos próprios autores, o que se dever ler para reter, para recolher e o que deve ser descartado e rejeitado. Diz Comenius que "a seleção dos textos deve ser feita prudentemente, para se não aprovar ou desaprovar qualquer coisa temerariamente" (Coménio, 1971, p. 308). A prudência abarcaria verificar quais foram as fontes nas quais cada autor se baseou para suas explicações e para seus comentários. Após essa averiguação, caberia consultar as mesmas fontes. Nas palavras de Comenius:
Isto significa que não devemos habituar-nos a servir-nos dos livros como de cadeirinhas ou de baloiços para nosso deleite, mas como de veículos ou de navios que nos conduzam mais além. Por isso, nunca se deve pegar num livro com outro fim que não seja tornar-se, sob qualquer aspecto, mais inteligente, ou mais prudente, ou melhor; nem se deve pôr um livro de lado, a não ser depois de extraído dele o conhecimento de uma coisa boa ou uma virtude mais plena. E também nunca devemos pôr de parte o autor lido, sem primeiro termos dele selecionado as flores e havermos transferido para as nossas colmeias, para as utilizarmos em qualquer necessidade presente (ou, ao menos, futura). (Coménio, 1971, p. 308)

\section{Ensinar todas as coisas por um método fácil e ágil}

Comenius considera que é de interesse público que a juventude seja formada em escolas públicas. A educação - lembra o educador - é a única possibilidade de fazer com que os dotes da natureza passem da potência ao ato. Comenius parte do princípio de que a criança vem de casa com costumes corrompidos, adquiridos exatamente em virtude da má educação doméstica. Nesse sentido, a escola seria voltada não apenas para o aprendizado dos saberes, mas também para o aprendizado da boa conduta, das normas consuetudinárias de comportamento. Mas as escolas, tal como se organizavam na época, não eram capazes de levar as crianças a desaprenderem o mal que receberam em casa. Ademais, as crianças, que chegavam à escola "depravadas pela primeira educação" (Coménio, 1971, p. 116), permaneciam poucas horas na escola; e, muitas vezes, eram submetidas a professores com maneiras indelicadas e com o costume de bater nos alunos. Comenius procura demonstrar que o que ele propõe é diferente:

1. Que se previna a corrupção dos costumes e dos espíritos, começando cedo uma boa educação; 2. Mantidos em intimidade de vida com pessoas sábias, honestas e ativas, não se permita aos alunos ver, ouvir e fazer nada que não seja sábio, honesto e pio; 3. E isto, não com um método enfadonho ou por meio de constrangimento, mas sempre tudo com exercícios atraentes e agradáveis e com jogos em comum. (Coménio, 1971, p. 116)

A escola de Comenius se contrapunha às escolas de seu tempo, mas também à prática de preceptoria. Comenius advoga aquilo que, tempos depois, será nomeado de ensino simultâneo. Ele acredita que ensinar individualmente o aluno seria perda de tempo, 
ocasionando um ensino mais lento e mais fatigante: "um só professor ensinará mais facilmente muitos alunos ao mesmo tempo, do que cada aluno individualmente" (Coménio, 1971, p. 118). Todavia a classe escolar seria subdividida em três grupos de alunos, dispostos por níveis de adiantamento. Cada uma dessas turmas teria um determinado nível para receber as aulas e os exercícios. Nesse sentido, o todo da classe era fraturado entre a turma de principiantes a turma dos adiantados e a turma dos mais adiantados.

A instituição projetada por Comenius tem uma lógica toda sua. Essa lógica interna ao funcionamento da escola envolve uma nova relação com o tempo e com o espaço. Supõe o estabelecimento de rotinas, que implicam períodos fixos para começar e para terminar as aulas, com o tempo distribuído por meses, por semanas, por dias e pelas horas de estudo a cada dia. Mais do que isso, haverá um programa a ser distribuído por tais períodos, em ritmo crescente, mediante o qual um conhecimento estará atado ao outro, produzindo uma rigorosa ordem entre as coisas. Nas palavras de Comenius, a estrutura da escola será análoga à estrutura de um relógio:

Um caminho que torna tudo mais fácil será seguir uma ordem rigorosa em todas as coisas. Ou seja, que cada escola seja como um cadeado, em que um anel, estando ligado a outro anel, torne o todo organicamente unido. E como um relógio, em que uma roda está de tal modo encaixada noutra roda que tudo se move, suavemente e harmonicamente, com um movimento uniforme. (Coménio, 1971, p. 119)

A ideia era a de ensinar todas as coisas por um método fácil, de maneira a favorecer que as crianças aprendam. Isso requereria "começar cedo, ensinar continuamente, exigir com suavidade a aplicação prática, 0 que permitirá progredir muitíssimo" (Coménio, 1971, p. 162). Comenius tinha verdadeira obsessão para que todos os alunos aprendessem. Nesse sentido, sua plataforma vinha expressa nas seguintes palavras: "ensinar de tal maneira que tudo o que for ensinado não possa não ser entendido" (Coménio, 1971, p. 164). Uma criança, de acordo com a Pampaedia, pode facilmente ser ensinada a ler e a escrever, apreendendo as coisas desde que estas sejam articuladas entre si, "deduzidas e princípios simples, dispostas gradualmente, à maneira e uma escada, de modo que todas as coisas precedentes preparem o caminho às que se seguem" (Coménio, 1971, p. 165). Para tanto, concretamente, o professor deveria principiar por mostrar ao aluno a "coisa inteira, a fim de que tudo o que lhe mandar aprender seja evidente diante dos olhos" (Coménio, 1971, p.165). Depois disso, as partes do objeto deveriam ser decompostas organicamente, para que se pudesse observar com clareza as partes componentes do objeto. Por fim, caberia ao aluno imitar o professor.
O ensino graduado era a grande estratégia de Comenius, e o que o diferenciava em relação a tudo o que até então já havia sido escrito sobre educação. 0 ensino graduado fazia com que cada etapa do ensino fosse o pavimento para preparar a fase imediatamente posterior, como se as matérias fossem concatenadas em um passo a passo, mediante o qual houvesse uma progressiva sistematização do saber, à luz da articulação das informações ministradas (Monroe, 1900, p. 48). Com tal método de ensino, os alunos não deveriam sentir o aprendizado como algo fatigante, já que todo processo agregaria exemplos, preceitos e exercícios. Além disso, tudo deveria ser feito por meio de jogos e de disputas, em conformidade com as idades dos alunos. 0 grande segredo, entretanto, era exatamente o de começar "sempre pelas primeiras coisas e mais baixas, e caminhando depois até as últimas e mais altas; de igual modo, das mais fáceis para as mais difíceis, até serem superadas também as dificílimas" (Coménio, 1971, p. 171). Os elementos isolados deveriam ser agrupados em combinações progressivamente mais complexas, o que levaria a que, por exemplo, na leitura, se passasse do alfabeto para as tábuas silábicas, depois até as palavras, para chegar às frases, e, por fim, aos textos. Esse grau crescente de dificuldade era a grande chave do método de Comenius, por meio do qual o autor ensinava a ensinar.

0 alfabeto deveria ser aprendido de cor, por ordem. Depois passar-se-ia às palavras monossílabas, depois às dissílabas, às trissílabas e às polissílabas. Daí se passaria às frases, de duas, de três e de mais palavras, frases voltadas para infundir "o temor de Deus e o conhecimento do que é honesto e do que é desonesto" (Coménio, 1971, p. 223). Comenius propõe um jogo. Escreve em dados algumas das letras. Joga o dado e as crianças precisam adivinhar qual é a letra que está escrita na face superior do dado. Primeiramente, são usadas apenas as vogais. Depois as consoantes. Finalmente utilizam-se as sílabas e depois as palavras. Sendo assim, por meio do jogo, as crianças estariam estudando e aprendendo. Comenius considera que o professor deve se valer de elementos intuitivos para ensinar, apresentando as coisas aos sentidos, de modo a que, por meio deles, se pudesse imprimir, no intelecto, a imagem da coisa demonstrada. Quando a coisa já é conhecida, o professor deve se valer do critério comparativo, conectando o objeto com outro semelhante. Por fim, para favorecer a abstração, o professor deveria utilizar o procedimento ideativo, que levaria a que o novo aprendizado pudesse efetivamente penetrar na mente como conhecimento. Esse seria, conforme o autor, o método pansófico. 


\section{O professor universal e seu ofício com crianças pequenas}

De acordo com a Pampaedia, a Escola Infantil de Comenius abarca seis classes:

\begin{abstract}
I. A classe puerperal, até a idade de um mês e meio; II. A classe do aleitamento, até a idade de um ano e meio; III. A classe do balbuceios e dos primeiros passos; IV. A classe da linguagem e da percepção sensível; V. A classe dos bons costumes e da piedade; VI. A primeira escola coletiva, ou seja, a classe das primeiras letras. (Coménio, 1971, p. 210)
\end{abstract}

Cabe notar que, nessa caracterização, Comenius estipula etapas da vida infantil. Nesse sentido, ele dá lugar à uma nova compreensão das diferentes fases da infância, cada um com seus padrões e com necessidades próprias. 0 ensino deveria, pois, adaptar-se às idades. Essa noção de idades da vida é fundamental no pensamento pedagógico de Comenius. Nas turmas de educação infantil, era necessário que os preceitos fossem breves:

Seja o que for que queiras ensinar, sê breve. Isto é, tudo aquilo que se ensina ou se diz, faça-se: 1 . no momento oportuno e de modo adequado ao assunto; 2. em pouco tempo; 3 . com clareza e com eficácia. Para que as crianças: 1 . ouçam com atenção; 2. entendam facilmente; 3 . retenham solidamente. De outro modo: 1. enfastiam-se facilmente; 2 . não entendem; 3 . se entendem no momento, não retêm. (Coménio, 1971, p. 214)

Diz Comenius que as crianças deveriam aprender os bons costumes, por exemplos, pela instrução e pela disciplina. Para o educador, "ensinar é guiar. Ora, guia aquele que vai à frente" (Coménio, 1971, p. 218). Se a criança tiver, assim, o bom exemplo daquele que a dirige, ela procurará agir bem, por imitação. Esse é o primeiro caminho do aprendizado: o exemplo. Coloca-se a necessidade de a criança ser protegida, de modo que "não veja, não ouça, não percepcione por qualquer sentido aquilo que deve ignorar" (Coménio, 1971, p. 218). A disciplina de Comenius não é - como era prática em seu tempo - aquela feita de açoites, mas consiste em uma atenção contínua do professor em relação a seus alunos para que estes façam o que deve ser feito.

A disciplina não deveria, então, ser rígida, mas "ministrada de modo que as crianças se apercebam que estão a ser observadas e que, se não cumprirem, serão castigadas; ao contrário, se se comportam bem, podem ser louvadas, mas com o rosto severo, para que sintam que se trata de coisas sérias" (Coménio, 1971, p. 222). Assim, progressivamente as crianças passam a perceber a diferença entre o jogo e as coisas sérias.

\section{A escola da puerícia e os primeiros fundamentos do edifício}

Sabe-se que a criança, entre os sete e os doze anos, naquela época, não era mais compreendida como criança. Essa etapa correspondia ao que os contemporâneos qualificavam por puerilidade. Na fase pueril, na perspectiva comeniana, os alunos deveriam aprender a fazer a sério as coisas sérias. 0 método deve possibilitar ao aluno ver por si, dizer por si, fazer por si e utilizar por si. Tal intenção requereria que fosse permitido aos pueris " 1 . ver, ouvir e tocar em tudo; 2. pronunciar, ler e escrever tudo; 3. desenhar e fazer tudo; 4. utilizar todas as coisas, segundo a maneira que lhes for mais útil" (Coménio, 1971, p. 235). Na escola da puerícia, correspondente à escolarização primária, a primeira classe teria três turmas: a primeira era a dos principiantes, que seriam aqueles que apenas soletram; a segunda turma era a dos adiantados, que seria correspondente aos que leem; e a terceira turma compreenderia os que já escrevem. É preciso lembrar que os alunos teriam contato com a leitura já no último ano do ensino infantil. Mas essa ideia de divisão das classes em três turmas é uma ideia-chave da organização didática de Comenius. Comenius, então, reconhece ritmos variados no aprendizado. Mas, segundo ele, todos têm possibilidade de aprender, posto que essa capacidade de aprender decorre de uma inclinação natural, que foi legada ao homem por Deus. Por tal razão, Comenius entende que o cérebro maleável da criança é capaz de penetrar nas coisas. Além disso, a puerilidade é dotada de muita curiosidade, que a leva a imprimir na memória, também com facilidade, tudo aquilo que aprende. Os alunos aprenderão facilmente - conforme a Pampaedia-, especialmente se se fizer uma repetição das coisas, o que proporciona uma "eficaz preparação da mente para estudos mais profundos" (Coménio, 1971, p. 259). Mais uma vez, Comenius destaca que a escola da puerícia era para todos, até porque Deus teria criado todos os homens com a habilidade de conhecer todas as coisas. Comenius não aceitava nenhuma distinção de classe para os assuntos da educação (Mayer, 1967, p. 227):

Regra geral: na Escola da Puerícia deve dar-se uma cultura geral, sem ter em consideração aquele que é nobre e aquele que é plebeu, e aquele que virá a ser artesão, comerciante, agricultor, sacerdote ou leigo, pois a escola é feita para ensinar coisas que serão úteis a todos, do mesmo modo que, no útero materno, são formados todos os membros de todos os homens. Portanto, lancemos as sementes da sabedoria universal em todos os espíritos dos 
jovens consagrados a Cristo, para que, se frequentarem os estudos até às escolas superiores (latinas), tenham uma cultura geral de base; e se se entregarem aos trabalhos manuais, possuam a cultura indispensável para lerem livros na língua materna, para escutarem as mais diversas conversas, mas sobretudo para lerem e para ouvirem a palavra de Deus. (Coménio, 1971, pp. 259-260)

Tratava-se, enfim, de um trabalho longo, que buscava organizar o saber em sua perspectiva didática, sua classificação, especificamente no tocante às dimensões da sequência, da gradação e da hierarquia dos saberes (Narodowski, 2001, 2006). Verifica-se em Comenius um plano daquilo que, na longa duração, a Europa faria, com o fito de conferir maior precisão a sua vida escolar. Esse movimento de um ensino simultâneo, que teria lugar efetivamente demarcado apenas do século XIX, é literalmente desenhado aqui. 0 ensino simultâneo estruturar-se-ia mediante uma liturgia, organizando-se à luz de uma relação entre quem ensina e quem é ensinado, pela mediação do livro, do caderno de notas e do método. Sobre esse método é que este trabalho se debruçará em seguida, por meio da análise da obra Didática Magna.

\section{Didática magna: tratado da arte universal de ensinar tudo a todos}

A Didática Magna - tratado da arte universal de ensinar tudo a todos (Coménio, 1985) - é uma obra de Comenius que foi publicada pela primeira vez em 1657 em Amsterdam e que constitui originalmente o que seria a tradução para o latim de sua obra anterior intitulada Didática checa. Todavia, Comenius, ao escrever esse novo texto em latim, acaba por modificar muitas de suas partes, "demasiadamente vinculadas à situação política contingente, e deixou de dedicá-la à nação boêmia, passando a dedicá-la a 'todos os que presidem os assuntos humanos, aos ministros de Estado, aos pastores da Igreja, aos diretores das escolas, aos pais, e aos preceptores dos jovens" (Fattori, 1997, p. 4). Comenius reescreve partes do texto, com o objetivo de torná-las mais compatíveis com suas ideias pansóficas. A Didática checa, por sua vez, permaneceu escondida como manuscrito por toda a vida de Comenius. Desconhecido, posteriormente, o original foi encontrado em 1841 e foi levado para a Biblioteca do Museu Nacional de Praga, cidade na qual a obra seria publicada pela primeira vez em 1849.

Na Didática Magna, Comenius caracteriza a situação das escolas de seu tempo e traça um plano para sua reorganização. Assim, como já ficou claro na análise anterior da Pampaedia, Comenius aqui quer a edificação de um modelo de escola no qual "todos aprendam totalmente tudo" (Comenius, 1997, p. 103). Comenius se incomodava com a situação das escolas de seu tempo, que tinham um método excessivamente duro, em virtude do qual eram "consideradas espantalhos para crianças e tortura para a mente: a maior parte dos alunos, enojada da cultura e dos livros, precipita-se para as lojas dos artesãos ou para alguma outra ocupação" (Comenius, 1997, p. 105). Tal como os professores ensinavam, "o que podia ser posto diante dos olhos de um modo perspícuo e claro era apresentado de modo obscuro incerto, intricado, como por meio de enigmas" (Comenius, 1997, p. 106). Além disso, os conhecimentos ministrados não eram substanciais, mas - no parecer de Comenius - eram "palavras superficiais, vãs, papagaiadas e opiniões que têm a consistência da palha e da fumaça" (Comenius, 1997, p. 106). Tudo o que era ensinado aos alunos propiciava fadiga e tédio, demorando anos até ser efetivamente aprendido. Comenius propunha uma proposta mais leve de escolarização, na qual a eficácia não se confundisse com o infringir de penas e de castigos. Em suas palavras:

Essa formação (...) seja tal que se desenvolva sem severidade e sem pancadas, sem nenhuma coarctação, com a máxima delicadeza e suavidade, quase de modo espontâneo (...) Todos sejam educados para uma cultura não vistosa mas verdadeira, não superficial mas sólida, de tal sorte que o homem, como animal racional, seja guiado por sua própria razão e não pela de outrem e se habitue não só a ler e a entender nos livros as opiniões alheias e a guardá-las de cor e recitá-las, mas a penetrar por si mesmo na raiz das coisas e delas extrair autêntico conhecimento e utilidade. A mesma solidez é necessária para a moral e a piedade. Que essa educação não seja cansativa, mas facílima: que aos exercícios de classe não sejam dedicadas mais de quatro horas, de tal modo que um só preceptor possa ensinar até cem alunos simultaneamente com um trabalho dez vezes menor do que o atualmente necessário para ensinar apenas um. (Comenius, 1997, p. 110)

É preciso lembrar que um dos interlocutores de Comenius é o professor particular, o preceptor, que vai à casa do pai de seus alunos e lá ensina apenas uma ou duas crianças. Outro interlocutor de Comenius são os colégios religiosos, que, especialmente no mundo católico, se organizavam no modelo do ensino jesuítico. Sabe-se que os jesuítas expandiram seu método de ensino para outras ordens religiosas do mundo católico. Por outro lado, mesmo os colégios dos países protestantes aplicavam uma pedagogia extremamente severa, contra a qual Comenius se insurgia. Era preciso, segundo o autor, redimensionar os critérios do que seria efetivamente ensinar bem. 


\section{A escola projetada e a escola real: a urgência da transformação}

0 plano de Comenius era o de que a infância e a juventude pudessem ser educadas "nas letras, nos costumes e na piedade" (Comenius, 1997, p. 112), sem o cansaço e todas as dificuldades que o método então em voga nas escolas proporcionava. 0 novo método deveria fazer com que a ação do professor coordenasse de tal maneira o processo do ensino que a classe e sua organização se tornariam assemelhados à estrutura de um relógio, no qual todas as partes, em sua mecânica, articulam um funcionamento estruturado. Cada um dos elementos componente do relógio teria uma finalidade, todas peças ligadas entre si, de tal maneira que "todos procedem com mais exatidão do que qualquer corpo vivo, movido pelo próprio espírito, e, se alguma peça se lascar, quebrar, despedaçar, soltar ou vergar" (Comenius, 1997, p. 127), ainda que fosse a peça mais pequenina e mais insignificante, imediatamente todo o relógio seria atingido e a mecânica deixaria de funcionar. Com isso, Comenius quer dizer que, na escola, a situação seria análoga: todos os elementos da escola estariam articulados, formando um todo ordenado. 0 grande segredo da Didática Magna seria o de assegurar a mecânica interna a esse conjunto. E esse conjunto implicava tempo, coisas e método. Nas palavras de Comenius:

\begin{abstract}
Portanto, a arte de ensinar não exige mais do que uma disposição tecnicamente bem feita do tempo, das coisas e do método. Se formos capazes de estabelecê-la com precisão, ensinar tudo a todos os jovens que vão à escola, sejam quantos forem, não será mais difícil que imprimir mil páginas por dia com bela escrita em caracteres tipográficos, transportar casas, torres e qualquer peso com a máquina de Arquimedes, ou navegar sobre o oceano e ir para o Novo Mundo. E tudo ocorrerá de modo tão fácil quanto o funcionamento de um relógio perfeitamente equilibrado pelos pesos. Tudo será tranquilo e agradável, assim como tranquilo e agradável é ver tal autômato, e será também tão seguro quanto um desses instrumentos criados pela arte. (Comenius, 1997, p. 127)
\end{abstract}

\section{Um novo sistema de ensino como imperativo da época}

Comenius acredita que as escolas não aproveitam o que ele chamava de "tempo oportuno para exercitar os engenhos" (Comenius, 1997, p. 148). 0 tempo precisava ser pensado sob todos os aspectos. A primeira coisa era a urgência de se projetar o tempo de se come- çar o ensino-o mais cedo possível, "quando o vigor da vida e da mente está em ascensão" (Comenius, 1997, p. 148). Mais do que isso, haveria de se planejar o tempo de ensinar, o ritmo de cada exposição, a duração de cada tarefa. De maneira correlata, era necessário equipar o espaço com todos os utensílios necessário para que o ensino se processasse adequadamente: "instrumentos, livros, quadros, exemplos e modelos" (Comenius, 1997, p. 149). Esses livros, porém, não eram os livros então em voga. Caberia escrever novos livros, nos quais as coisas fossem dispostas de maneira ordenada, e onde ficasse evidente a primazia da realidade sobre o conhecimento que se tem dela.

\begin{abstract}
$\mathrm{Na}$ escola ensinam as palavras antes das coisas: durante vários anos, as mentes ficam empenhadas nas artes dissertativas, e só depois, não sei quando, são-lhe apresentadas as ciências reais, como a matemática, a física, etc. Todavia, visto que as coisas são substância e as palavras são acidentes, que as coisas são o corpo e as palavras são o ornamento, que as coisas são o cerne e as palavras são a casca e o envoltório, elas devem ser apresentadas ao intelecto humano conjuntamente, mas antes as coisas que são objeto tanto do intelecto quanto do discurso. (Comenius, 1997, p. 150)
\end{abstract}

Para Comenius da Didática Magna, era preciso primeiramente formar o entendimento das coisas, depois a memória e finalmente a língua e as mãos. Não fazia sentido, segundo ele, formar a juventude "ditando muitas coisas e obrigando decorá-las, sem uma cuidadosa explicação" (Comenius, 1997, p. 156). Era errado também fazer, como se fazia na época, uma espécie de enxerto na cabeça das crianças do conhecimento das diferentes ciências. Ensinar não é enxertar. Comenius se recorda que, quando estudou, foi sobrecarregado com regras prolixas, com comentários de textos clássicos e com exegeses dos comentários. Assim é que se era introduzido sobretudo, nos estudos da dialética, da retórica e da metafísica: "atulhavam-nos de gramática latina, com todas as suas exceções, e de gramática grega, com os vários dialetos, e nós, pobrezinhos, ficávamos atordoados, sem entender o que se passava" (Comenius, 1997, p. 158).

Ora, era necessário ensinar as ciências. Era necessário atrelar o conhecimento ensinado à realidade concreta da vida dos alunos. Era preciso começar o ensino pelo aprendizado da língua materna. Mas, principalmente, era fundamental que o ensino começasse pela demonstração dos rudimentos das coisas, expondo em linhas gerais a base dos assuntos a serem ensinados. Desse modo, Comenius, aqui também, insiste na gradação do conhecimento apreendido pelo aluno, em uma estratégia de formação na qual 
haja "uma disposição tal dos assuntos que os estudos futuros pareçam ser apenas um desenvolvimento pormenorizado dos que os precederam" (Comenius, 1997, p. 158). 0 alicerce do método de Comenius era o ensino graduado; e a razão para isso é a de que a própria "natureza não procede por saltos, mas gradualmente" (Comenius, 1997, p. 159). Todas as coisas aprendidas deveriam parecer, aos olhos de quem aprende, interligadas. Conforme observa Comenius:

Que na mente das crianças que devam dedicar-se aos estudos sejam inculcadas as bases de uma instrução universal desde o primeiro momento da formação, ou seja, uma disposição tal dos assuntos que os estudos futuros pareçam ser apenas um desenvolvimento pormenorizado dos que os precederam. É isso o que acontece com a árvore, mesmo que tenha cem anos: não lhe nascem galhos novos, mas os já nascidos no início ampliam-se em outros tantos galhos. Que qualquer língua, ciência ou arte seja ensinada no início apenas por meio de rudimentos simples, de modo que delas se tenha uma ideia geral para depois se aprimorar o estudo por meio de regras e exemplos, e, em terceiro lugar, por meio de sistemas completos, incluindo as irregularidades; finalmente, se necessário, que sejam incluídos comentários. Na verdade, quem compreende uma coisa desde seus fundamentos não precisa de comentários; aliás, pouco depois, poderá fazê-los por conta própria. (Comenius, 1997, pp. 158-159)

\section{$O$ aprendizado pelas coisas, a ordem das coisas e o conhecimento}

Comenius se preocupa com a circunscrição da escola. Esta deveria ser situada em local tranquilo, "distante da turba e das distrações" (Comenius, 1997, p. 162). É preciso que o ensino se dê sem qualquer tipo de interrupção e não se deve permitir ao aluno qualquer tipo de afastamento das aulas. Comenius fala com uma realidade na qual não havia a ideia de um ano letivo. Portanto, os alunos iam para a escola quando lhes fosse mais conveniente, em geral nos meses nos quais não trabalhavam nos campos. Comenius alerta que é "prejudicial mandar as crianças para a escola a intervalos de meses e de anos, distraindo-as com outras ocupações" (Comenius, 1997, p. 161). Considerando que o aprendizado deveria vir pela apreensão das coisas, estas precisariam estar ordenadas. Os estudos necessitavam, portanto, ser distribuídos para os alunos e um assunto sucederia naturalmente ao outro, uma matéria se complementaria na outra, de tal maneira que, como em uma espiral, cada ramo do saber se interligasse ao conhecimento mais elementar, por um lado, e ao conhecimento mais avançado, por outro. Além disso, cada matéria deveria ser completada em um determinado limite de tempo. Sendo assim, haveria de se obedecer alguns preceitos: 1 . os estudos seriam distribuídos, tanto para a preparação das aulas por parte do professor quanto para a organização dos alunos; 2. os saberes ensinados deveriam suceder-se e concatenar-se uns aos outros; 3 . cada matéria teria um tempo para ser ministrada. Comenius argumenta com as seguintes palavras:

I. Todas as matérias de estudo devem ser divididas em aulas, de tal modo que as primeiras sempre aplanem e iluminem o caminho das seguintes. II. O tempo deve ser bem distribuído para que, a cada ano, mês, dia, hora, seja atribuída uma tarefa particular. III. A medida do tempo e dos trabalhos deve ser rigidamente observada, para que nada seja esquecido ou invertido. (Comenius, 1997, p. 160)

Comenius estruturava claramente uma rotina para sua classe. Tinha critérios para organizar um modo de agir do professor, que, segundo ele, asseguraria o êxito do ensino ministrado. 0 processo do ensino deveria começar cedo. Dever-se-ia passar das coisas mais gerais para as particulares, das mais fáceis para as mais difíceis. Era imprescindível que se despertasse nas crianças o amor pelo conhecimento. Esse amor pelo estudo deveria ser suscitado pelos professores, pela escola e pelo método. Mas os pais também teriam um papel de relevo nessa direção:

\footnotetext{
Os pais conseguirão levar os filhos a aceitar com amor o ensino e o mestre se diante deles louvarem frequentemente a cultura e as pessoas cultas; se, exortando-os a ser diligentes, prometerem livros graciosos, roupas ou alguma coisa agradável; se elogiarem o mestre (sobretudo aqueles aos quais confiaram a educação dos filhos), seja pela excelente cultura, seja pela atitude amável em relação aos alunos (porque o amor e a admiração são sentimentos bastante fortes para estimular a emulação); se, enfim, os enviarem ao mestre com algum recado ou algum presentinho. (Comenius, 1997, p. 169)
}

Os professores, por sua vez, precisariam conquistar o coração das crianças, para que elas tenham vontade de passar mais tempo na escola do que em casa. Isso significava "não as assustarem de modo algum com austeridade, mas, ao contrário, as atraírem com afeto, gestos e palavras paternais" (Comenius, 1997, p. 169). Os estudos deveriam ser sempre exaltados e as crianças mais diligentes deveriam ser recompensadas, inclusive com pequenos prêmios. Além disso, o mestre deveria com frequência se aproximar das crianças com o fito de lhes mostrar coisas que deverão 
aprender no futuro. Todo o contato entre professor e aluno deveria ser pautado pela amabilidade. 0 amor ao estudo seria, enfim, estimulado pelo próprio método de ensino. Comenius vê no método a chave de sua educação. 0 método, por sua vez, seria inscrito em regras breves e exatas: "toda regra deve ser concebida com palavras brevíssimas, mas muito claras. Toda regra deve ser exemplificada com muitíssimos exemplos que esclareçam todas as variações no uso dessa regra" (Comenius, 1997, p. 172).

\section{Princípios da facilidade do ensinar e do aprender}

Comenius compreende que as escolas deverão seguir uma ordem ditada pela própria natureza; e que elas contrariam essa ordem quando ensinam o desconhecido por meio do próprio desconhecido. Por exemplo, o ensino do latim era feito em latim - com as regras da língua latina explicadas em latim. Além disso, os colégios da época ensinavam a língua materna através do latim, o que era, para Comenius, uma total impropriedade: "isso porque eles não aprendem o vernáculo através do latim, mas precisam aprender o latim através da língua materna, que já conhecem" (Comenius, 1997, p. 173). As escolas contrariam a ordem da natureza também quando instruem toda a juventude de todas as nações com as mesmas regras gramaticais, "ao passo que cada língua tem sua relação própria e peculiar com a língua latina, que deve ser descoberta se quisermos que as crianças conheçam perfeitamente a natureza própria do latim" (Comenius, 1997, p. 173). Qual seria, portanto, a estratégia para a correção de tais desvios? A implementação do método. Este, por sua vez, requereria que professores e alunos falassem a mesma língua materna e que todo ensino por ela fosse iniciado. As explicações do professor deveriam, sendo dadas na língua pátria do aluno, tornar-se acessíveis à compreensão plena da criança. A língua materna, em suma, precederia a língua latina e todo o ensino de outras novas línguas. Este, quando ocorresse, deveria ser ministrado gradualmente, "de tal modo que o aluno se acostume a entender (isso é muito fácil), depois a escrever (quando tem tempo de meditar) e finalmente a falar (e isso é muito difícil, porque deve ser espontâneo" (Comenius, 1997, p. 174). Todos os ensinamentos necessitariam ser acompanhados de exemplos, retirados da realidade dos alunos; lembrando que se exercitaria primeiramente "os sentidos das crianças (e isso é muito fácil), depois a memória, o intelecto e, finalmente, o juízo" (Comenius, 1997, p. 174). Com tal orientação,
Comenius rejeita os próprios pressupostos que organizavam o ensino dos colégios de seu tempo; e abaixo ele descreve a realidade de tais escolas:

Portanto, é uma tortura para os jovens: 1) ficar ocupados durante seis, sete, oito horas por dia com aulas e exercícios coletivos e depois também solitários; 2) ter de fazer ditados, exercícios e aprender de cor o maior número de coisas, até a náusea e a loucura, como com frequência ocorre. Se alguém quisesse encher à força um frasco de boca estreita (que pode ser comparado à mente das crianças), em vez de pôr o líquido gota a gota, o que obteria? A maior parte do líquido cairia fora e entraria quantidade bem menor do que se ele fosse posto gota a gota. Portanto, mostra ser muito inepto quem se põe a ensinar aos alunos o que lhe apraz, e não o que eles entendem, pois as forças devem ser ajudadas, e não oprimidas, e o educador, assim como o médico, é apenas um ministro, e não senhor da cultura. (Comenius, 1997, p. 176)

Todo o ensino deveria, pois, ser proporcional à capacidade dos alunos e ao estágio de seu desenvolvimento. Com os progressos dos estudos, ampliar-se-ão as habilidades dos alunos. Mesmo assim, é necessário cuidar para que a memória fosse exercitada, sempre com parcimônia, para não sobrecarregar, não fatigar e não levar os alunos ao completo desinteresse pelas coisas do estudo. As aulas não deveriam durar mais de quatro horas. No projeto comeniano, as mentes nunca seriam forçadas a fazer coisas superiores à sua idade e a sua capacidade. Não seriam também "obrigadas a aprender de cor ou a fazer coisas que não foram antes explicadas, esclarecidas ou ensinadas" (Comenius, 1997, p. 177). Os alunos deverão desejar aprender e essa condição precisará ser, pelo ensino, desenvolvida. Só se conceberia que o aluno fosse levado a decorar aquilo que efetivamente seu intelecto já teria dominado: "e só se deve pedir à criança que repita de memória aquilo que, com certeza, ela entendeu bem" (Comenius, 1997, p. 178). Comenius rejeita o professor que atribui uma tarefa qualquer a seus alunos, sem explanar minuciosamente antes, elucidando, inclusive as dúvidas que os alunos pudessem ter.

É insensível o preceptor que, atribuindo uma tarefa aos alunos, não lhes explica do que se trata nem de que modo deva ser feita, muito menos os ajuda enquanto eles tentam realizá-la, mas ao contrário os obriga a suar e a agitar-se, enfurecendo-se quando não fazem bem alguma coisa. 0 que é isso senão tortura para os jovens? É como se uma aia quisesse obrigar a andar depressa uma criancinha que ainda não se sustentasse com segurança sobre as pernas, e, se ela não fosse capaz, a obrigasse à força das chicotadas. 0 que a natureza nos ensina 
é bem diferente, ou seja, que devemos tolerar a fraqueza enquanto o vigor não chega. Do que foi dito, conclui-se que: I. para ensinar não se deve aplicar nenhuma chicotada (se não se aprende, a culpa é só do preceptor, que não consegue tornar o aluno dócil); II. tudo que se queira ensinar ao aluno deve ser exposto e demonstrado de modo claríssimo, como se fossem os cinco dedos das mãos; III. para que todas as coisas sejam impressas mais facilmente, é preciso fazer o máximo uso dos sentidos. (Comenius, 1997, p. 179).

Os assuntos estudados precisariam ser de alguma utilidade. Além disso, os princípios do objeto de estudo deveriam ser sólidos e aprofundados. Todo o aprendizado deverá estar ancorado por algum aprendizado anterior, de maneira a que haja uma articulação entre o que é posterior e o que é aquilo que hoje se poderia compreender como "conhecimento prévio" do aluno. Comenius recomenda: "nada se imprime com firmeza na mente se antes não for entendido com correção pelo intelecto e confiado com exatidão à memória" (Comenius, 1997, p. 194). Comenius insiste na necessidade de se ter um método para ensinar todos os alunos de uma mesma classe. Todos, ao mesmo tempo, aprendendo juntos. Outro aspecto que é extremamente inovador na acepção de método de Comenius é sua sugestão de que o ensino da leitura e da escrita seja feito paralelamente e em conjunto. Isso-conforme o autor-não apenas serviria para economizar tempo, mas também despertaria nos alunos maior prazer pelo conhecimento das letras e das palavras.

Mas as escolas de seu tempo não se mostravam capazes de estabelecer metas e de traçar os roteiros que conduziriam às referidas metas.

As artes e as ciências eram ensinadas de modo enciclopédico, em poucos lugares e, mesmo assim, de modo fragmentário. Por isso, era como se, diante dos olhos dos alunos, houvesse uma montanha de madeira e de sarmentos, mas ninguém conseguisse entender a razão da conexão entre eles: acontecia, então, que um conseguia captar um conceito, outro captava outro, sem que a instrução de todos fosse universal e bem fundamentada. Os métodos eram múltiplos e variados: cada escola, aliás, cada preceptor, tinha um; acontecia até mesmo de um preceptor usar um método para determinada arte ou língua, outro para outra e - o que é pior - mudar de método até para ensinar a mesma matéria, e por isso raramente os alunos entendiam do que se estava tratando. Daí derivavam dúvidas e atrasos, e às vezes certas disciplinas causavam tanta náusea e enjôo antes mesmo que os alunos fossem postos diante delas que muitos sequer sentiam vontade de experimentá-las. (Comenius, 1997, p. 205)

Comenius acredita que o professor era como se fosse o sol, que, com os mesmos raios, distribui sua luz para todas as coisas. Isso significa que o ensino será simultâneo que deverá haver, pelo menos, um professor para cada classe de alunos. Além disso, em cada matéria, deveria existir um único autor. Todas as disciplinas deveriam ser ensinadas com o mesmo método. Todo o ensino deve fincar-se sobre degraus progressivos de complexidade, sendo todos esses interligados. Em defesa do ensino simultâneo, Comenius argumenta que, quando são poucos os alunos que escutam o professor, deles poderá escapar alguma coisa. Já quando são muitos os alunos, "cada um entenderá o que puder, mas, com sucessivas repetições, tudo voltará à mente, para proveito de todos; o engenho de um afia o do outro, e a memória de um afia a do outro" (Comenius, 1997, p. 209). Comenius era obcecado com o que hoje chamaríamos de eficácia da escola. Era preciso que a instituição fosse bem-sucedida naquilo que se propõe a fazer: ensinasse não um, ensinasse não poucos, ensinasse não alguns, mas ensinasse todos os alunos. E, para tanto, o educador traçava algumas comparações:

Numa palavra, assim como o padeiro assa muitos pães e o oleiro faz muitos tijolos com uma só massa e esquentando o forno uma só vez, assim como o tipógrafo com uma única composição de caracteres produz centenas e milhares de exemplares de livros, também o mestre, sem nenhum esforço, pode ensinar, ao mesmo tempo, os mesmos exercícios a um grande número de alunos; assim também vemos que um único tronco basta para sustentar uma árvore muito grande e frondosa e para propiciar-lhe a linfa vital, e que o sol é suficiente para que cresçam as plantas de toda a terra. (Comenius, 1997, p. 209)

Comenius deu à Pedagogia uma teoria do ensino pautada por um método: não o método que vigorava, em seu tempo, nos colégios, mas um novo método, pautado no aprendizado pelos sentidos e pelo conhecimento prévio do estudante. A proposta de organização tanto do ensino simultâneo quanto da escola graduada pode ser atribuída ao educador checo, com a antecedência de alguns séculos até que efetivamente tal orientação viesse a ser implementada. Comenius, nesse sentido, é um autor que precisa ser estudado para que possamos verificar os fundamentos do nosso atual modelo escolar, que regula e organiza toda a vida cultural contemporânea. 


\section{Conclusão: a escola como compromisso público}

Comenius projeta uma escola renovada para um mundo em turbulência que seria - também ele renovado. Tendo passado toda sua vida adulta em meio à Guerra dos 30 Anos, Comenius desenvolve a tese de que a educação letrada deve ser ministrada nas escolas de maneira universal. Tratava-se, pois, de ensinar a todos: meninos e meninas, ricos e pobres, nobres e plebeus. 0 ensino abarcaria preceitos, exemplos e experiências. Para ensinar crianças, havia de se começar sempre pelas coisas e pela percepção sensível. Daí se formaria, progressivamente, uma cultura geral enciclopédica, formadora de pensamentos, de palavras e de ações. 0 método de Comenius abarcava alguns aspectos que são essenciais. 0 primeiro deles era que o conhecimento deveria ser, antes de tudo, entrelaçado, com os saberes encaixados uns nos outros, formando uma teia na qual se transitasse da matéria mais fácil para a mais complexa, em graus crescentes de dificuldade. Nessa direção, é possível dizer que Comenius é um dos pioneiros do ensino graduado. Outro fator importante para descrever o método de Comenius é o de compreender que se tratava de uma proposta de ensino simultâneo, na qual todos os alunos são ensinados ao mesmo tempo, como se fossem um só. 0 ensino da leitura e da escrita também seriam processos concomitantes e paralelos. Tudo isso agilizaria o ensino e facilitaria o aprendizado. Comenius compara a escola com a mecânica do relógio, com a arte da tipografia e com o ofício do padeiro: as peças deveriam ser interligadas uma a outra em prol do funcionamento do conjunto e a ação de um único mestre-assim como a prensa e como o padeiro-geraria não um livro, mas centenas deles; não um pão, mas dezenas deles; não um aluno, mas uma classe inteira...

Comenius integra uma história da escola e do pensamento pedagógico que se remete a uma busca de obediência a regras impessoais. Antes de tudo, é importante salientar que a forma da escola não é o efeito de uma sociedade que se transformava. Ela integra a transformação e faz parte dela. Ao mesmo tempo em que a escola se impunha na vida social, a sociedade progressivamente adquiria — com o acúmulo da cultura escrita e com a disseminação da cultura impressa-uma forma inédita de relação social: a pedagogização das outras instituições. 0 funcionamento da escola impunha a obediência a regras impessoais. Tratava-se de uma configuração histórica singular, que codificava saberes, valores e atitudes, engendrando efeitos de socialização duráveis. 0 resultado disso consistirá naquilo que alguns autores vão chamar de "forma escolar de socialização" (Vincent; Lahire; Thin, 1994). As características da forma escolar de socialização, supondo a codificação da organização das atividades escolares, são: 1. constituição de universo separado da infância; 2. regras impessoais de ensino e aprendizado; 3 . organização racional do tempo; 4. multiplicação e repetição dos exercícios; 5. Configuração de hábitos de higiene, obediência, perseverança, atenção, assiduidade, pontualidade e auto-confiança. A história dessa forma escolar não se deu sem contradições e lutas, dado que ela se contrapunha a outros sistemas de formação. Para Dizem Vincent, Lahire e Thin (1994) sobre o tema:

\begin{abstract}
Parta-se, portanto, da invenção da forma escolar, para compreender como, não sem dificuldades, um modo de socialização escolar se impôs a outros modos de socialização, para discernir também quais são seus caracteres principais e tudo aquilo que faz parte dessa configuração histórica singular, ao passo que se tem a tendência de crer que ela é, senão natural, pelo menos, eterna e universal: a pedagogia, as disciplinas, etc. Há que se compreender, enfim, como a hipótese de uma pedagogização das relações sociais poderia dar conta de interpretar, de maneira paradoxal, a crise atual. (p. 14)
\end{abstract}

Quais são os desafios da escola contemporânea? Procurar-se-á sistematizar abaixo os três grandes conjuntos de dilemas que a escola, em nossos dias, enfrenta.

1. A ideia republicana de uma escola para todos não foi capaz de eliminar de seus quadros as desigualdades - tanto as desigualdades sociais que, vindas do exterior, penetram na escola, como também as desigualdades entre os alunos que a própria escola cria e reiteradamente reforça. Nesse sentido, no interior do universo escolar, há vencedores e há vencidos; e, via de regra, a classificação escolar corresponde à fratura existente no jogo societário, de maneira geral. A escola contemporânea, até para poder defender sua matriz republicana, precisará dar conta de superar tais contradições e se estruturar de maneira a assegurar a todas as crianças efetivamente as mesmas oportunidades de ter uma trajetória escolar bem-sucedida.

2. A crise do universalismo também é enfrentada pela escolarização. A escola sempre apresentou como universais os saberes de que dispõe, a despeito do fato de se reconhecer que a cultura que por ela veiculada é-ela própria-fruto da linhagem da mesma cultura escolar. Nesse sentido, deve-se concordar com Chervel (1998) quando ele diz que "contrariamente ao que se poderia pensar, a teoria gramatical ensinada na escola não é a expressão das ciências ditas, ou presumidas, de referência, mas ela é historicamente 
criada pela própria escola, na escola e para a escola" (p. 14). Seja como for, essa escola, no mundo ocidental, sempre lidou com um conteúdo ocidentalizado em suas narrativas. Tratava-se de enfatizar, à luz da história centrada na Europa, um determinado roteiro de desenvolução do conhecimento, o qual, apresentado como universal, tinha a marca de uma cultura dominante, de uma cultura vencedora. A escola contemporânea pede a mudança desse formato, agregando a si novos conteúdos, que venham a expressar a visão dos vencidos, dos dominados.

3. Por fim, a escola, hoje, ainda, dialoga muito mal com as novas tecnologias digitais. A sociedade contemporânea colocou para os educadores o grande desafio de se buscar manter os princípios pedagógicos da formação, contemplando as novas formas de se acessar a informação. 0 fato é que, comparadas a gerações anteriores, as crianças que entram na escola hoje possuem outra relação com o conhecimento, que passa pela internet; uma outra relação com a sociabilidade, que passa pelo instagram, pelo whatsapp, pelo facebook, pelo twitter; uma nova relação com a comunicação, que passa pelo celular. Sem que esses recursos sejam explorados pela escola, corre-se o risco de não se poder superar a obsolescência que, mais cedo ou mais tarde, tomará conta da instituição.

Pensar na atualidade de Comenius requer que nos indaguemos acerca desses três grandes desafios. Comenius desenhou, com sua obra, a forma da escola, tal como ela, ainda hoje, sob muitos aspectos, permanece. Há de se compreender o que pode ser, desse formato, preservado e o que deverá ser descartado e substituído. Assim como não faz sentido aderir a modismos, também não se pode, em nome da permanência, recusar a inovação. Porém, deve-se ter cautela para compreender a escolarização como uma experiência outra, que rompe com as relações primárias e assim deve ser:

É nesse sentido que devemos entender a capacidade criadora da cultura por meio da educação: o poder ilustrar e romper tradições. Esta foi uma das principais funções que a modernidade lhe atribuiu: a de poder alterar os folkways (caminhos populares) ou maneiras de pensar e de fazer que foram recebidos. (...) A cultura do popular e do local, a cultura do grupo de referência não podem ser o guia fundamental para estabelecer os currículos escolares. Sem um certo grau de domínio dos conhecimentos científicos não é possível interagir com os sistemas abstratos que maciçamente se infiltram na vida cotidiana, porque, hoje, a vida e a sociedade são complexas. (...) Todos os conhecimentos formalizados depositados em elaborações objetivas têm a potencialidade de aumentar a experiência dos sujeitos e da sociedade, porque permitem o acesso àquilo que está afastado no tempo e no espaço, àquilo que não é imediato, à experiência de outros, ao que eles pensaram. Este é o valor da cultura, na concepção moderna. (Sacristán, 1999, p. 126)

Por fim, pode-se dizer que a leitura de Comenius nos faz pensar na escola passada, na escola atual e na escola futura: na escola passada porque ela é contemporânea da época que engendrava, pelos colégios, um inédito sistema de formação; na escola atual porque muitos traços do que se visualiza ainda hoje na escolarização eram já existentes na narrativa de Comenius; e na escola futura porque não conseguimos conceber outra escola para o porvir, sem o ponto de referência que é o nosso-e que, em alguma medida, foi o dele. Comenius é atual porque é um clássico e "os clássicos são aqueles livros que chegam até nós trazendo consigo as marcas das leituras que precederam a nossa e atrás de si os traços que deixaram na cultura ou nas culturas que atravessaram" (Calvino, 2009, p. 18). Porque continua falando à nossa contemporaneidade, Comenius é um autor que nos convida a abraçá-lo e nos impele a refutá-lo. Que venha a posteridade. E que Comenius não seja por ela esquecido.

\section{Referências}

Bédard, J. (2005). Comenius ou combattre la pauvreté par l'éducation de tous. Liber.

Cauly, O. (1999). Comenius: o pai da pedagogia moderna. Instituto Piaget.

Chervel, A. (1998). La culture scolaire: une approche historique. Belin.

Calvino, I. (2009). Por que ler os clássicos. Companhia das Letras.

Coménio, J. A. (1971). Pampaedia (educação universal). Coimbra: Faculdade de Letras da Universidade de Coimbra.

Coménio , J. A. (1985). Didática magna. Fundação Calouste Gulbenkian.

Comenius, J.A. (1997). Didática magna. Martins Fontes.

Crouzet, M. (1995). História geral das civilizações: os séculos XVI e XVII - os progressos da civilização europeia. Bertrand Brasil.

Fattori, M. (1997). Introdução. In: Comenius (1997). Didática magna (pp. 3-9). Martins Fontes.

Gomes, J. F. (1985). Introdução. In: Coménio (1985). Didática magna (pp. 5-41). Fundação Calouste Gulbenkian. 
Gomes, J. F. (1971). Introdução. In: Coménio (1985). Pampaedia (educação universal) pp. 7-29. Faculdade de Letras da Universidade de Coimbra.

Julia, D. (2001). A cultura escolar como objeto histórico. Revista Brasileira de História da educação, 1(1), 9-43.

Kulesza, W. (1992). Comenius: a persistência da utopia em educação. Editora da Unicamp.

Mayer, F. (1967). Historia del pensamiento pedagógico. Editorial Kapelusz.

Monroe, W. S. (1900). Comenius and the beginnings of educational reform. Charles Scribner's Sons.

Narodowski, M. (2001). Infância e poder: conformação da pedagogia moderna. Edusf.

Narodowski, M. (2006). Comenius e a educação. Autêntica.

Nóvoa, A. (1991). O passado e o presente dos professores. In Nóvoa, A. (1991). Profissão professor, pp 9-32. Porto Editora.
Nóvoa, A. (1998). Relação escola-sociedade: novas respostas para um velho problema. In: Serbino, R. V.; Ribeiro, R.; Barbosa, R. L. L.; Gebran, R. A. (Orgs.) (1998). Formação de professores pp. 19-39. Fundação Editora Unesp.

Piobetta, J. B. (s/d). Jean Amos Comenius. In: Chateau, J. Os grandes pedagogos (pp. 125-143). Edição Livros do Brasil.

Sacristán, J. G. (1999). Poderes instáveis em educação. Porto Alegre.

Vincent, G.; Lahire, B.; Thin, D. (1994). Sur l'histoire et la théorie de la forme scolaire. In Vincent, G. L'éducation prisionniére de la forme scolaire: scolarisation et sociailisation dans les societés industrielles pp.11-48. Presses Universitaires de Lyon. 